\title{
Clinical experience in the management of pulmonary opportunist infection and rejection in recipients of heart-lung transplants
}

\author{
A R L PENKETH, T W higenbotTAM, J HUTTER, C COUTTS, S STEWART, \\ J WALLWORK
}

From the Departments of Respiratory Physiology, Pathology and Cardiothoracic Surgery, Papworth Hospital, Cambridge

\begin{abstract}
The main clinical problems that follow heart-lung transplantation are opportunis $\vec{b}$ infections of the lungs and pulmonary rejection. Of 23 patients undergoing heart-lung transplantas tion, eight had opportunist infections and 12 had at least one episode of pulmonary rejection. Cardia\& rejection occurred in only one patient, who did not need treatment. Of the 12 patients who had pulmonary rejection, nine recovered fully after augmented immunosuppression with high dosê corticosteroids, although one patient required additional low dose corticosteroids for eight months before making a full recovery. Fatal opportunist lung infection followed treatment for rejection in two patients. One patient developed obliterative bronchiolitis. Of the eight patients with opportunis infections, five had primary cytomegalovirus pneumonitis, acquired from the donor. All three्e patients treated with acyclovir died, whereas the two treated with hyperimmune globulin anco dihydroxy proxymethylguanine recovered fully. Two patients developed Pneumoncystis carinit pneumonia, which was treated successfully in one patient with intravenous sulphadimidine anc5 trimethoprim. The other patient died after a further episode of rejection and aspergillus bronchitis One patient developed a tuberculous empyema. The calculated actuarial survival at one year was़. $78 \%$ and at two years $67 \cdot 2 \%$. Although it is still in its innovative stage heart-lung transplantation appears to have complications and results similar to those of transplantation of other organs.
\end{abstract}

\section{Introduction}

Successful human heart and lung transplantation with cyclosporin to produce immunosuppression was first reported in $1982 .{ }^{1}$ More than 300 operations had been performed worldwide by 1986 . $^{2}$ Three main complications have been reported in long term survivors of the operation: opportunist infection of the lungs, acute pulmonary rejection, and chronic disabling obliterative bronchiolitis. ${ }^{34}$ Infection is common and an important cause of early death. ${ }^{4}$ The diagnosis and management of acute rejection had caused difficulty until recently because of the lack of a reliable diagnostic test, ${ }^{5}$ but transbronchial biopsy has been shown to be adequate for histological diagnosis. ${ }^{6}$

Address for reprint requests: Dr TW Higenbottam, Department of Respiratory Physiology, Papworth Hospital, Papworth Everard, Cambridge CB3 8RE.

Accepted 14 July 1988
Clinical and experimental work suggests thati obliterative bronchiolitis is related to chronic rejec 3 tion $^{57}$ and its incidence has fallen with greatero experience in the regulation of immunotherapy. ${ }^{4}$ Wes report our experience of these problems in 23 patients and describe our current management strategy for both opportunist infection and pulmonary rejection.

\section{Patients and methods}

Twenty three patients underwent heart-lung transeo plantation at Papworth Hospital from April 1984 tô April 1987; one patient also received a liver transplant $\stackrel{\infty}{+}$ The original diagnoses are shown in table 1 and detailso of perioperative and maintenance immunosuppres sion in table 2. The criteria for patient and donor selection and the operative procedure have been $\vec{B}$ previously reported ${ }^{89}$ Antibiotic prophylaxis consisted of intravenous flucloxacillin ( $500 \mathrm{mg}$ six hourly) and ceftazidime ( 1 g eight hourly) given at induction of 
Table 1 Diagnoses of 23 patients with heart-lung transplants

\begin{tabular}{lc}
\hline Diagnosis & $\begin{array}{l}\text { No of } \\
\text { patients }\end{array}$ \\
\hline Primary pulmonary hypertension & 2 \\
Pulmonary hypertension secondary to emboli & 3 \\
Eisenmenger's syndrome & 9 \\
Primary pulmonary hypertension and primary & 1 \\
biliary cirrhosis & 2 \\
Emphysema & 2 \\
Sarcoidosis and pulmonary hypertension & 1 \\
Histiocytosis X & 1 \\
Bystic fibrosis & 1 \\
Cryptogenic fibrosing alveolitis & 1 \\
Total & -23 \\
\hline
\end{tabular}

anaesthesia and for $\mathbf{4 8}$ hours postoperatively. Patients remained in intensive care during antithymocyte globulin treatment for an average of five days. They were discharged from the ward to a hospital flat in the third or fourth week after the operation and seen three times a week for a further fortnight before returning home. They were then seen every two weeks up to three months, every three months up to one year and six monthly thereafter.

\section{POSTOPERATIVE ASSESSMENT}

At routine follow up an electrocardiogram and chest radiograph were obtained. Pulmonary function assessment consisted of measurement of dynamic lung volumes (one second forced expiratory volume $\left(\mathrm{FEV}_{1}\right)$ and forced vital capacity (FVC), total lung capacity (TLC) measured by whole body plethysmography, and single breath gas transfer for carbon monoxide (TLCO)).

Cyclosporin concentrations were assayed in whole blood and plasma ("Cyclotrak" radioimmunoassay, Immunonuclear). Blood urea and serum creatinine concentrations and full blood counts were performed to monitor the effects of cyclosporin and azathioprine. Blood glucose and fasting lipids were also measured.

Serological tests for cytomegalovirus and toxoplasma were performed at intervals. Antibody to cytomegalovirus was detected by a complement fixation test and a competitive ELISA method. ${ }^{10}$ Primary cytomegalovirus infection was diagnosed in patients who developed appreciable titres (a greater than fourfold rise in titre according to the complement fixation test or more than $50 \%$ inhibition in competitive ELISA), having had no detectable serum antibody before transplantation. Reactivation of cytomegalovirus infection was defined by a greater than fourfold rise in cytomegalovirus antibody according to the complement fixation test. In all cases infection was confirmed by detection of cytomegalovirus specific IgM by the $\mu$ capture ELISA method of Wreghitt et al."
Routine endomyocardial biopsies were performed initially, ${ }^{12}$ but this practice was discontinued in May 1987. It has been replaced by bronchoscopy and transbronchial lung biopsies, which are carried out routinely at four monthly intervals and then annually.

Further investigations were performed if patients complained of a cough, breathlessness, malaise, or fever, or had crackles or wheeze on auscultation of the chest. Abnormalities on routine chest radiographs and falls of $15 \%$ or more in $\mathrm{FEV}_{1}$ or FVC from previous values were also used as indications for further investigations. Blood, sputum, and urine cultures were then performed together with serological tests for cytomegalovirus, respiratory viruses, and toxoplasmosis. Fibreoptic bronchoscopy was performed by standard techniques and transbronchial biopsy samples were taken with "alligator" forceps (Olympus, Keymed, Maidstone). Four to six samples were taken from the area of maximum radiographic shadowing if present, or from basal segments of one lower lobe.

Besides routine histological preparations, biopsy samples were fixed in formalin and stained for fungi and Pneumocystis carinii. Mycobacterial stains were performed if indicated clinically. Bronchial washings were cultured for fungi, mycobacteria, and bacterial pathogens. Culture of washings and biopsy material for viruses was not attempted for logistic reasons.

Pulmonary rejection was diagnosed histologically from transbronchial biopsy specimens. ${ }^{6}$ Pneumocystis carinii pneumonia was diagnosed by the presence of a foamy exudate containing silver staining cysts, and cytomegalovirus pneumonitis was diagnosed histologically from the presence of typical inclusion bodies or on the basis of changes suggesting a "viral"

Table 2 Immunosuppressive protocol used for patients with heart-lung transplants

\begin{tabular}{|c|c|c|}
\hline Drug & Perioperative dose & Maintenance dose \\
\hline $\begin{array}{l}\text { Cyclosporin } \\
\text { Methylprednisolone }\end{array}$ & $\begin{array}{l}5-10 \mathrm{mg} / \mathrm{kg} \text { daily } \\
500 \mathrm{mg} \text { IV } \times 2 \\
125 \mathrm{mg} \text { IV } \times 3\end{array}$ & $\begin{array}{l}5-10 \mathrm{mg} / \mathrm{kg}^{-1} \mathrm{day}^{-1} \dagger \\
-\end{array}$ \\
\hline $\begin{array}{l}\text { Equine } \\
\text { antithymocytic } \\
\text { globulin }\end{array}$ & $\begin{array}{l}5 \mathrm{mg} / \mathrm{kg} \text { daily (for } 5 \\
\text { days) }\end{array}$ & - \\
\hline Prednisolone & - & $\begin{array}{l}\text { Started on } 2 \mathrm{nd} \\
\text { perioperative day at } \\
0.5 \mathrm{mg} / \mathrm{kg} \text { daily, } \\
\text { reducing to } 0.2 \mathrm{mg} / \\
\text { kg at } 2 \text { weeks; } \\
\text { usually stopped at } 1 \\
\text { month }\end{array}$ \\
\hline Azathioprine & - & $\begin{array}{l}1-2 \mathrm{mg} / \mathrm{kg} \text { daily } \\
\text { after } 1 \text { month } f\end{array}$ \\
\hline
\end{tabular}

*Dose adjusted to reduce the $T$ cell fraction of the total lymphocyte count to approximately $10 \%$.

†Cyclosporin dose adjusted according to renal function and plasma trough concentration $(200-500 \mathrm{ng} / \mathrm{ml})$.

Azathioprine dose adjusted to give a white cell count of $5.0 \times 10^{9} / 1$ IV-intravenously. 
alveolitis in conjunction with a fourfold rise in cytomegalovirus IgM antibody. In all patients with cytomegalovirus pneumonitis the diagnosis was confirmed by the presence of inclusion bodies in repeated biopsy samples or by the histological findings at necropsy.

\section{TREATMENT}

During episodes of rejection patients were given daily intravenous boluses of $0.5 \mathrm{~g}$ methyl prednisolone for three days and oral prednisolone $1 \mathrm{mg} / \mathrm{kg}$ daily reducing to zero over a two week period. One patient was treated with $10 \mathrm{mg}$ of prednisolone daily for eight months. Pneumocystis carinii pneumonia was treated with trimethoprim $15 \mathrm{mg} / \mathrm{kg}$ per day and sulphadimidine $2 \mathrm{~g}$ four times daily intravenously for 10 days followed by oral co-trimoxazole $3840 \mathrm{mg}$ (Septrin eight tablets) daily for four weeks. ${ }^{13}$

The first three patients with cytomegalovirus pneumonia were treated with intravenous acyclovir. From September 1986 patients who were known to be cytomegalovirus "mismatches" (that is, seronegative recipients with organs from seropositive donors) were treated prophylactically with hyperimmune globulin postoperatively. They received a weekly intramuscular injection of cytomegalovirus specific gammaglobulin until they either developed disease, seroconverted without apparent disease, or were finally discharged from hospital. It was known whether the donor was cytomegalovirus seropositive within $\mathbf{4 8}$ hours of surgery and the first dose was given at that time. Cytomegalovirus negative blood products were not available for use in these patients as this diagnosis was made only after surgery. Later patients with cytomegalovirus pneumonitis received intravenous DHPG (9(1,3-dihydroxy-2-propoxymethyl) guanine) at a dose of $5 \mathrm{mg} / \mathrm{kg}$ for 14 days (Wellcome Foundation, Crewe).

\section{Results}

SUR VIVAL AFTER TRANSPLANTATION

There were no operative deaths. Two early deaths occurred, one from tracheal dehiscence after $\mathbf{4 4}$ days
Table 3 Opportunist infections in 23 patients with heart-lung transplants

\begin{tabular}{|c|c|c|}
\hline Infection & $\begin{array}{l}\text { No of } \\
\text { patients }\end{array}$ & $\begin{array}{l}\text { No of } \\
\text { deaths }\end{array}$ \\
\hline $\begin{array}{l}\text { Primary cytomegalovirus infection } \\
\text { Ileum and stomach } \\
\text { Lung } \\
\text { Pneumocystis carinii pneumonia } \\
\text { Tuberculous empyema }\end{array}$ & $\begin{array}{l}1^{*} \\
5 \\
2 \\
1^{*}\end{array}$ & $\begin{array}{l}0 \\
3 \\
1 \\
0\end{array}$ \\
\hline
\end{tabular}

and one from cerebral infarction after 12 days. Three of the 23 patients died from primary cytomegaloviruss pneumonitis in the first month. Eighteen patients weres discharged from hospital, and 16 are well two months to three years after transplantation. One patient died at 14 months of respiratory failure after several rejection episodes and severe Pneumocystis carinin pneumonia. At necropsy there was evidence of obliterative bronchiolitis and pulmonary fibrosis, $\stackrel{\mathscr{}}{-}$ some rejection, and bronchial infection with Asper $\vec{\imath}$ gillus fumigatus. One patient died 30 months aftero transplantation from obliterative bronchiolitis. The calculated actuarial survival of the 23 patients to one year was $78 \%$ and to two years $67 \cdot 2 \%$.

\section{OPPORTUNISTIC INFECTION}

Eight of the 23 patients developed pulmonary oppor $\cong$ tunist infection (table 3). One had a tuberculous empyema 18 months after transplantation, which ${ }^{3}$ responded to treatment with three antituberculous drugs. The patient had been treated for suspected. tuberculosis in 1971 and had received long term corticosteroids for fibrosing alveolitis before transplantation in 1984. Two patients developed Pneumocystis carinii pneumonia at five and 12 months after operation. Both had had episodes of pulmonary rejection in the previous three months and had augmented immunosuppressive treatment (cortico-o steroids).

Nine of the 23 transplant recipients were sero은 negative for cytomegalovirus before operation and received organs from seropositive donors (table 4) N One seroconverted without clinical disease and ono

Table 4 Outcome for nine patients with heart-lung transplants who were seronegative for cytomegalovirus (CMV) before operation and received organs from seropositive donors

\begin{tabular}{|c|c|c|c|}
\hline Postoperative complication & No of patients & $C M V$ status & Outcome \\
\hline \multicolumn{4}{|l|}{ Primary CMV infection } \\
\hline $\begin{array}{l}\text { Ileum } \\
\text { Lung }\end{array}$ & $\begin{array}{l}1 \\
5\end{array}$ & $\begin{array}{l}\text { Seroconversion } \\
\text { Seroconversion }\end{array}$ & $\begin{array}{l}\text { Survived; well } 3 \text { y after transplantation } \\
3 \text { deaths; } 2 \text { patients survived and are we } \\
6 \text { months after transplantation }\end{array}$ \\
\hline Obliterative bronchiolitis & 1 & Seroconversion & $\begin{array}{l}\text { Severely disabled; died awaiting } \\
\text { retransplantation }\end{array}$ \\
\hline None & 1 & $\begin{array}{l}\text { Seroconversion } \\
\text { Seronegative }\end{array}$ & $\begin{array}{l}\text { Well } 18 \text { months after transplantation } \\
\text { Well } 16 \text { months after transplantation }\end{array}$ \\
\hline
\end{tabular}


Table 5 Features of pulmonary rejection episodes in 12 heart-lung transplant patients

\begin{tabular}{|c|c|c|c|c|c|c|}
\hline $\begin{array}{l}\text { Patient } \\
\mathrm{No}^{*}\end{array}$ & $\begin{array}{l}\text { Time after } \\
\text { transplantation }\end{array}$ & $\begin{array}{l}\text { Respiratory } \\
\text { symptoms }\end{array}$ & $\begin{array}{l}\text { \% change } \\
\text { in } F E V,\end{array}$ & $\begin{array}{l}\text { Chest } \\
\text { radiograph } \\
\text { abnormal }\end{array}$ & $\begin{array}{l}\text { Transbronchial } \\
\text { biopsy confirmed } \\
\text { rejection }\end{array}$ & Outcome \\
\hline $\begin{array}{l}1 \\
2\end{array}$ & $\begin{array}{l}21 \mathrm{~m} \\
18 \mathrm{~m} \\
20 \mathrm{~m} \\
23 \mathrm{~m}\end{array}$ & $\begin{array}{l}+ \\
+ \\
+ \\
+\end{array}$ & $\begin{array}{l}-26 \\
-25 \\
\text { No change } \\
\text { No change }\end{array}$ & $\begin{array}{l}- \\
\overline{-} \\
-\end{array}$ & $\begin{array}{l}\text { Not done } \\
+ \\
+ \\
+\end{array}$ & $\begin{array}{l}\text { Recovered } \\
\text { Recovered } \\
\text { (see fig 1) }\end{array}$ \\
\hline 3 & $5 \mathrm{~m}$ & + & $\begin{array}{l}-24 \\
\text { No change }\end{array}$ & 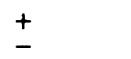 & $\begin{array}{l}+ \\
+\end{array}$ & $\begin{array}{l}\text { Obliterative } \\
\text { bronchiolitis; died } 30 \mathrm{~m}\end{array}$ \\
\hline $\begin{array}{l}6 \\
8 \\
9\end{array}$ & $\begin{array}{l}1 \mathrm{~m} \\
14 \mathrm{~m}\end{array}$ & $\frac{+}{+}$ & $\begin{array}{l}-36 \\
-44 \\
-13\end{array}$ & $\overline{-}$ & $\begin{array}{l}+ \\
+ \\
+\end{array}$ & $\begin{array}{l}\text { Recovered } \\
\text { Recovered } \\
\text { Died of cytomegalovirus } \\
\text { infection at } 4 \mathrm{w}\end{array}$ \\
\hline 10 & $\begin{array}{l}5 \mathrm{~m} \\
5 \frac{1}{2} \mathrm{~m} \\
9 \mathrm{~m} \\
11 \mathrm{~m}\end{array}$ & $\begin{array}{l}+ \\
+ \\
+ \\
+\end{array}$ & $\begin{array}{l}-18 \\
\text { No change } \\
\text { No change } \\
\text { No change }\end{array}$ & $\begin{array}{l}- \\
\bar{t}\end{array}$ & $\begin{array}{l}+ \\
+ \\
+ \\
+\end{array}$ & $\begin{array}{l}\text { Died of pulmonary } \\
\text { fibrosis, rejection } \\
\text { and Aspergillus } \\
\text { fumigatus bronchitis at } 14 \mathrm{~m}\end{array}$ \\
\hline $\begin{array}{l}11 \\
15\end{array}$ & $2 \mathrm{~m}$ & $\begin{array}{l}- \\
+ \\
2 \mathrm{~m}\end{array}$ & $\begin{array}{l}+9 \\
\text { Not done } \\
+\end{array}$ & $\begin{array}{l}+ \\
+\end{array}$ & $\begin{array}{l}\text { Not done } \\
+ \\
-\end{array}$ & $\begin{array}{l}\text { Recovered } \\
\text { Recovered } \\
+\end{array}$ \\
\hline $\begin{array}{l}16 \\
18\end{array}$ & $\begin{array}{l}6 \mathrm{~m} \\
3 \mathrm{w} \\
5 \mathrm{w}\end{array}$ & $\begin{array}{l}+ \\
+\end{array}$ & $\begin{array}{l}+5 \\
-33 \\
\text { No change }\end{array}$ & $\begin{array}{l}\bar{t} \\
+ \\
+\end{array}$ & \pm & $\begin{array}{l}\text { Recovered } \\
\text { Recovered }\end{array}$ \\
\hline 21 & $3 w$ & + & -17 & + & + & Recovered \\
\hline
\end{tabular}

*In order of transplantation.

has remained seronegative. The other seven patients acquired a primary cytomegalovirus infection within three months of transplantation. In one patient, whose infection of the stomach and small bowel was diagnosed by gastric mucosal biopsy, infection resolved without treatment. Five patients developed cytomegalovirus pneumonitis. The first three were treated with acyclovir, the diagnosis having been made by transbronchial biopsy, but all died. In the subsequent two patients cytomegalovirus infection was suspected at an early stage on clinical grounds and because they had seroconverted. Initial transbronchial biopsy samples showed extensive alveolar damage but no inclusion bodies; later biopsy samples contained inclusion bodies. Both patients were treated with DHPG (Wellcome) and recovered fully. The ninth patient seroconverted with minimal symptoms but subsequently had four episodes of pulmonary rejection, which failed to respond to augmented immunosuppression. She developed obliterative bronchiolitis and died 30 months after transplantation.

\section{REJECTION}

Twenty episodes of pulmonary rejection were diagnosed in 12 of the 23 patients. Eight episodes occurred in the first three months, but rejection could occur at any time during follow up. On three occasions patients were symptom free; two episodes were diagnosed by "routine" transbronchial biopsy and one because of an abnormal chest radiograph. The other patients complained of cough and breathlessness and there was often a low grade pyrexia. Wheezes were usually heard on auscultation with late inspiratory crackles. The chest radiograph was abnormal in only eight of the 20 episodes. On five occasions concurrent endomyocardial biopsy samples were normal. Transbronchial biopsy, performed on 18 occasions, confirmed the diagnosis in 16 but there were two false negatives (these two episodes responded to treatment). One patient on one occasion showed evidence of mild to moderate cardiac rejection. The remaining 105 cardiac biopsies yielded normal specimens.

Table 5 gives the clinical details of these episodes of rejection. Pulmonary function was measured at the time of the first episode of rejection in 11 of the 12 patients. No measurements could be made in the other patient, in whom rejection occurred very early after

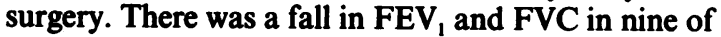
the 11 patients, but only inconsistent changes in gas transfer were observed (table 6).

Of the 12 patients with rejection, two developed opportunist infections and died shortly after being given augmented immunosuppression; one (No 9) died of cytomegalovirus infection one month after

Table 6 Changes in lung function at the first documented rejection episode in 11 patients with heart-lung transplants

\begin{tabular}{ll}
\hline $\begin{array}{l}\text { Lung function } \\
\text { variable }\end{array}$ & $\begin{array}{l}\text { Mean }(S D) \text { change as \% of } \\
\text { previous routine measurements }\end{array}$ \\
\hline FEV & $-21(11 \cdot 9)$ \\
FVC & $-15 \cdot 7(10 \cdot 3)$ \\
RV & $+19(25 \cdot 6)$ \\
TLC & $+4.5(8.7)$ \\
KCO & $+7.8(38.5)$ \\
\hline
\end{tabular}




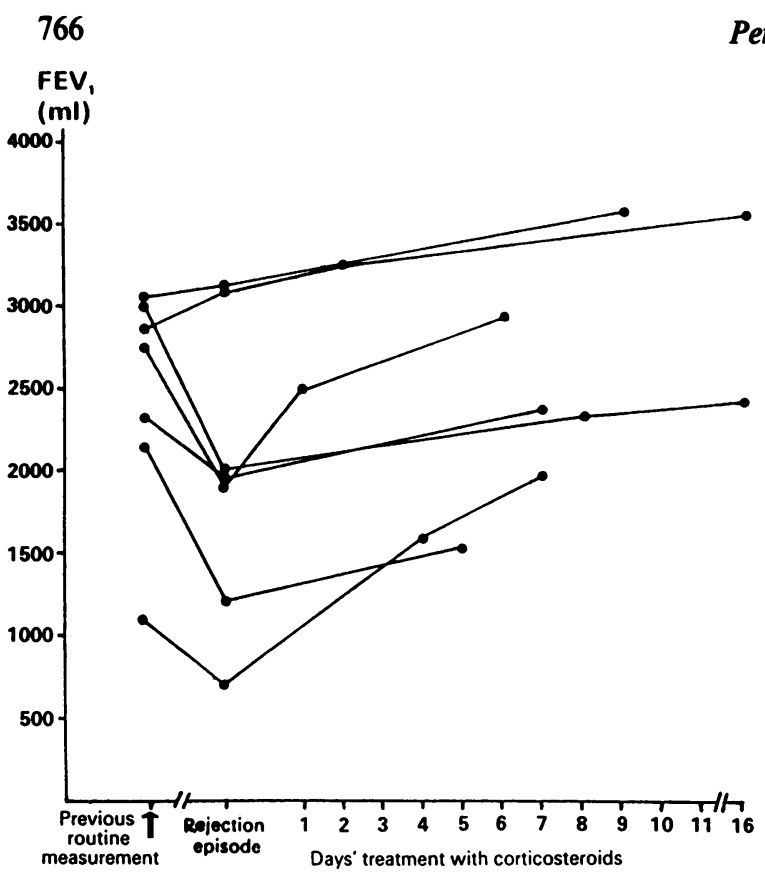

Fig 1 Forced expiratory volume in one second (FEV $)$ of seven recipients of heart-lung transplants during their first documented episode of pulmonary rejection. The values are the best routine measurement before the episode of rejection, at the time of transbronchial biopsy, and during corticosteroid treatment.

surgery; and one (No 10) never recovered from Pneumocystis carinii pneumonia, dying finally from invasive aspergillosis and obliterative bronchiolitis 14 months after transplantation (table 5). One patient (No 3) had an episode of rejection five months after operation, which initially responded to standard augmented immunosuppression; but she relapsed catastrophically when this was stopped. Her FEV 1 fell from 2.6 to 0.751 in a few days and her FVC fell from 2.8 to 2.11 , but there was no change in gas transfer. Further treatment with steroids had only marginal benefit. An open lung biopsy carried out later confirmed obliterative bronchiolitis; the patient died 30 months after transplantation.

Nine of the 12 patients who experienced rejection ultimately recovered after treatment and achieved normal lung function and exercise tolerance. Eight patients had improved considerably within a week (fig 1). One patient (No 2) responded poorly to treatment of a rejection episode 18 months after transplantation and a further biopsy two months later still showed active rejection. Another short course of corticosteroids had little effect. A third biopsy at 23 months showed active rejection, which was treated conventionally, but the patient was then given maintenance prednisolone $10 \mathrm{mg}$ daily for eight months. He
Penketh, Higenbottam, Hutter, Coutts, Stewart, Wallwork recovered normal lung function and a repeat biopş showed normal lung tissue.

\section{OTHER HOSPITAL ADMISSIONS}

After their initial discharge 10 patients were readmis ted to hospital on 20 occasions for problems othe than opportunist infection or rejection. On sip occasions the problem was not infective; renal colic (t) case), steroid myopathy (1), vaginal bleeding (1), and non-specific abdominal pain and vomiting (3). The other 14 admissions were for infections not usually classified as opportunist. One patient had bilaterap otitis media requiring surgical intervention and one $\vec{\Phi}$ pyelonephrosis that required nephrectomy. The otherd 12 patients had infections of the respiratory tract, tw with lobar pneumonia due to Streptococcus pneumono iae treated with intravenous penicillin and one with $\vec{a}$ mild influenza-like illness and dry cough, presumed to be caused by a virus, which resolved with no trea $\vec{P}$ ment. The other nine patients had a productive cough but no change on the radiograph and so were conto sidered to have acute bronchitis. Organisms were grown from the sputum in six cases (Staphylococcuis aureus (1 case), H influenzae 1, Streptococcus pneumone iae 4). Routine treatment was intravenous amoxycillin $500 \mathrm{mg} 8$ hourly with flucloxacillin $500 \mathrm{mg} 6$ hourl until culture results were available.

\section{Discussion}

The initial reports on combined heart-lung transplant tation recorded a high perioperative mortality of 21 $26 \%,{ }^{34}$ largely due to bleeding from the chest walb Four of our patients had bleeding that necessitate further surgery, but all survived. Our predicte $\phi$ actuarial survival of $78 \%$ at one year compares. favourably with that of the Stanford group (71\%) and is better than the worldwide experience of $50 \% .22$

The most frequent cause of opportunist infectiog was cytomegalovirus, which resulted in symptomatic illness in six patients $(26 \%)$. This is similar to the. figures of $21 \%$ in recipients of heart-lung transplants, and $34 \%$ in those receiving a heart transplant alone and those having heart-lung transplants. ${ }^{16}$ The lattes series, from Dummer et al, ${ }^{16}$ included eight cases of cytomegalovirus pneumonia and showed a much greater incidence of pneumonia after combined hearto lung transplantation (four of five patients) than after transplantation of the heart only (four of 44 patients)? They suggested that pulmonary rejection or greatero immunosuppression might predispose tQ cytomegalovirus infection in the transplanted lung. If contrast to these reports, our patients with primar $\overrightarrow{8}$ cytomegalovirus pneumonitis had all acquired it from the donor organs, compared with one out of three in the Standford series ${ }^{15}$ and two out of four in the 


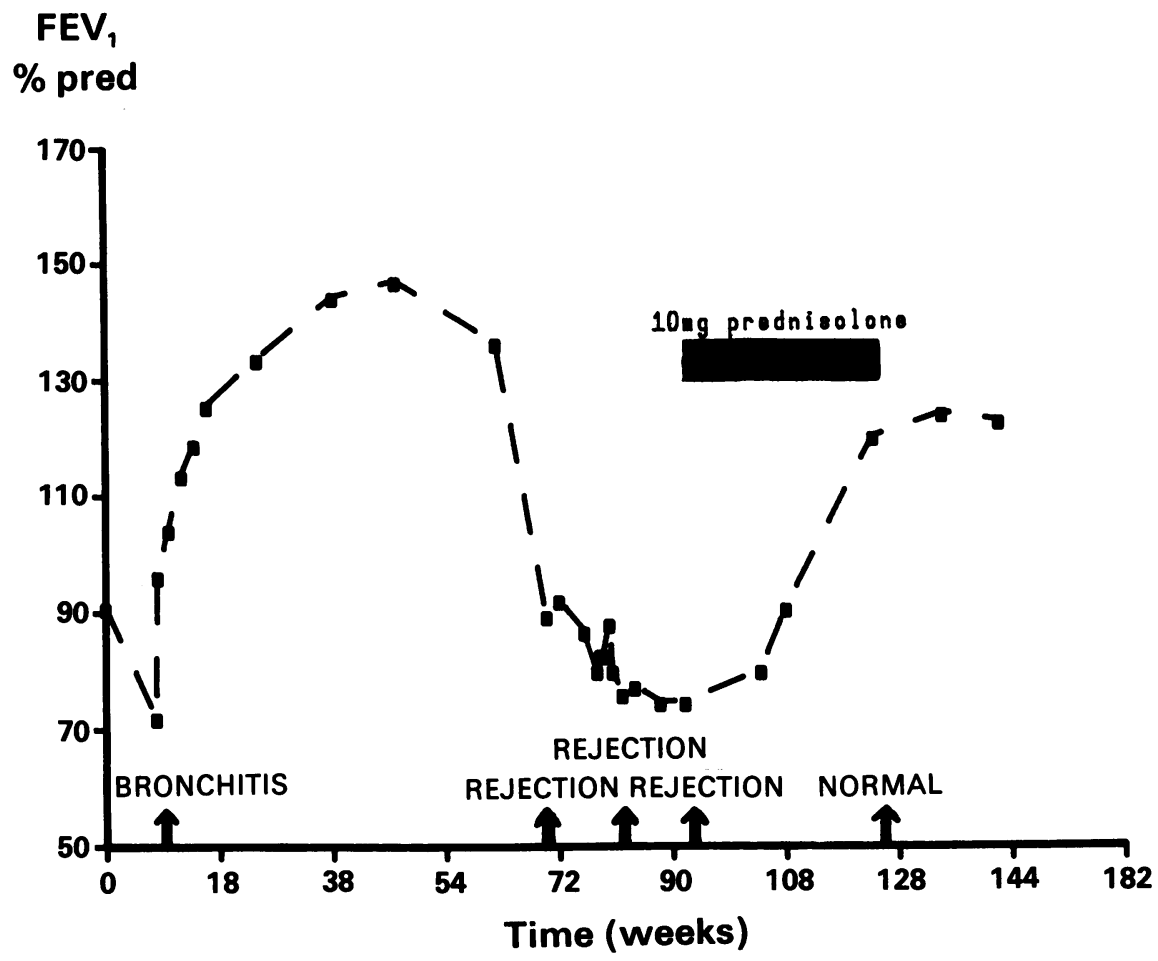

Fig 2 Forced expiratory volume in one second $\left(F E V_{1}\right)$ of patient 2, who experienced three episodes of pulmonary rejection and who received prolonged low dose prednisolone (10 $\mathrm{mg}$ daily). Arrows indicate transbronchial biopsy and high dose corticosteroids.

Pittsburgh series. ${ }^{16}$ Cytomegalovirus infection from the donor organ has been described in other forms of organ transplantation. ${ }^{1718}$

We have assumed that the cytomegalovirus infections in these patients were acquired from the donor organs rather than blood products because of the severity of the disease. Unfortunately we do not have sufficient cytomegalovirus negative blood products to cover all operations. We did not know until after the operation and after blood transfusion had taken place whether the donor was cytomegalovirus seropositive. In the larger heart transplant programme at our institution $27 \%$ of cytomegalovirus negative recipients receiving organs from cytomegalovirus negative donors have developed primary infection with the virus, presumably from blood products. The disease was much milder in these patients and there were no deaths (TG Wreghitt, personal communication). Possibly blood products were the source of the infection in some of our patients, though none of our four patients who were cytomegalovirus seronegative and received matched negative organs and so were potentially at risk only from blood product infection has so far shown seroconversion.
The problem of cytomegalovirus infection from the donor can be avoided if the donor serotype is known before the operation and seropositive donor organs are used only in seropositive recipients. New, rapid methods for measuring cytomegalovirus antibody are now available 19 and our current practice is to "match" donors and recipients for cytomegalovirus status. When cytomegalovirus "mismatch" became apparent in three patients they were treated with prophylactic hyperimmune globulin after operation, but all developed cytomegalovirus pneumonitis. Experience with hyperimmune globulin in recipients of bone marrow transplants suggests that it is not very effective. $^{18}$

The two most recent patients with cytomegalovirus infection were also treated with the antiviral agent DHPG, which has been shown to have some effect on cytomegalovirus infections in patients with bone marrow transplants and with AIDS. ${ }^{20}$ The fact that these patients survived whereas the three treated with acyclovir died also suggests that this agent may be more effective in cytomegalovirus infections than is acyclovir. Dummer et $a l^{16}$ found that acyclovir was ineffective. Cytomegalovirus infection invariably 
occurred within the first three months after transplantation, as noted by others, and this offers a useful guide to diagnosis of pulmonary infection early after transplantation.

Pneumocystis carinii pneumonia was the most common infection reported by Griffiths et $\mathrm{al}^{4}$ and these authors suggested that antibiotic prophylaxis should be given to patients undergoing heart-lung transplantation. Prophylaxis has been shown to be very effective in bone marrow transplantation. ${ }^{21}$ We have not used co-trimoxazole prophylaxis routinely because of the additional risk of bone marrow suppression in patients also receiving azathioprine. Our two patients developed infection with Pneumocystis carinii shortly after a course of augmented immunosuppression and a similar association with immunosuppressive treatment was seen in our patients with heart transplants in $1986 .{ }^{22}$ Our practice now is to give co-trimoxazole prophylaxis (Septrin, one tablet daily) selectively to patients who require augmented immunosuppression. The low dose of co-trimoxazole was selected because of the risk of marrow suppression. No cases of pneumocystis pneumonia in patients with either heartlung or heart transplants have occurred in the six months since this practice was instituted. For acute pneumocystis pneumonia trimethoprim was given with sulphadimidine rather than sulphamethoxazole, to minimise the risk of further renal damage in patients receiving cyclosporin. ${ }^{13}$

Of this small series of 23 patients, 12 had one or more episodes of pulmonary rejection. This is similar to the incidence of rejection in recipients of renal transplants given cyclosporin $\mathrm{A}$ and azathioprine. ${ }^{23}$ The incidence of pulmonary rejection has not been given in other series, ${ }^{34}$ largely because of the lack of any method of diagnosis short of an open lung biopsy. It was initially thought that the heart and lungs would be rejected simultaneously, so that endomyocardial biopsy ${ }^{812}$ could be used to monitor rejection. It is now known that the organs are rejected independently ${ }^{24}$ and in our experience the lung is the more vulnerable organ. Transbronchial biopsy provides adequate material for diagnosis of rejection based on the histological appearance of perivascular lymphocytic infiltration. ${ }^{6}$ We have now abandoned routine cardiac biopsy.

Recipients of transplants have an acute perception of dyspnoea, complaining of breathlessness with quite minor degrees of physiological impairment. In addition, the lung has an advantage over other transplanted organs in that physical signs can be detected and monitored easily. Any patient who develops respiratory symptoms or crackles or wheezes on auscultation undergoes lung function tests followed by bronchoscopy. A reduction in $\mathrm{FEV}_{1}$ or FVC without symptoms or signs is also an indication for broncho- scopy and transbronchial lung biopsy. Our experience with patient 2 suggests that the treatment of rejectiog should be more prolonged if a good physiologica response is not seen within a week. Careful monitoring of lung function may be used to assess the efficiency of augmented immunosuppression. We no longer give an arbitary course of two weeks of increased cortic $\overrightarrow{0}$ steroids. Pulmonary function testing renders the man agement of heart-lung transplantation similar to thos of other organ transplantation.

Obliterative bronchiolitis occurred as the sole pathx ological feature in only one patient in the present seriess and only one in that of Griffith et al. ${ }^{4}$ It was, however, $\vec{\Phi}$ major complication in the Stanford series, found in half of the patients who survived the operation at mean of 11 months after surgery. ${ }^{3}$ Only seven patien 8 in the present series and eight in the Pittsburgh series have so far survived beyond one year, but from the Stanford experience we would have expected more cases of bronchiolitis. Close monitoring of lung fune? tion and the early diagnosis of pulmonary rejection by transbronchial biopsy may have contributed to oug low incidence of obliterative bronchiolitis.

In our unit only cytomegalovirus "matches" are now accepted. Patients who experience rejection are treated more aggressively and earlier with longe courses of corticosteroids and they are also give prophylaxis against Pneumocystis carinii pneumoni? Heart-lung transplantation is in its infancy but $\overrightarrow{a 3}$ experience increases the mortality is being reduced..$^{s \bar{B}}$

\section{References}

1 Reitz BA, Wallwork J, Hunt SA, et al. Heart-lung transplantation: successful therapy for patients with pulmonary vascular disease. $N$ Engl $J$ Med 1982;306:557-64.

2 Solis E, Kaye MP. The registry of the Internationa Society for Heart-transplantation: third official report Heart Transplantation 1986;5:2.

3 Burke CM, Baldwin JC, Morris AJ, et al. Twenty eighi cases of human heart-lung transplantation. Lancep 1986;i:517-9.

4 Griffith BP, Hardesty RL, Trento R, et al. Heart-lung transplantation; lessons learned and future hopes. Am Thorac Surg 1987;43:6-16.

5 Copeland JG. Heart-lung transplantation; current statu\& [Editorial]. Ann Thorac Surg 1987;43:2-3.

6 Higenbottam T, Stewart S, Wallwork J. Transbronchia lung biopsy to diagnose lung rejection and infection heart-lung transplants. Transplant Proc 1988;20(supe? 1):767-9.

7 Youseman SA, Burke CM, Billingham ME. Pathological pulmonary alterations in long-term human heart-lung transplantation. Hum Pathol 1985;16:911-23.

8 Reitz BA. Heart-lung transplantation: a review. Hea f Transplantation 1982;1:291-7.

9 Jamieson SW, Stinson EB, Oyer PE, Baldwin JC, Shum way NE. Operative technique for heart-lung transplaro 
tation. J Thorac Cardiovasc Surg 1984;87:930-5.

10 Wreghitt TG, Hicks J, Gray JJ, O'Connor C. Development of a competitive enzyme-like immunosorbent assay for detecting cytomegalovirus antibody. $J$ Med Virol 1986;18:119-29.

11 Wreghitt TG, Gray JJ, Chandler C. Prognostic value of cytomegalovirus IgM antibody in transplant recipients. Lancet 1986;i:1157-8.

12 Caves PK, Billingham ME, Stinson EB, Shumway NE. Serial transvenous biopsy of the transplanted human heart. Lancet 1974;i:821-7.

13 Jones DK, Hakim M, Wallwork J, Higenbottam TW. A serious interaction between cyclosporin $A$ and sulphadimidine. Br Med J 1986;292:728-9.

14 Dawkins KD, Jamieson SW, Hunt SA, et al. Long-term results, haemodynamics and complications after combined heart-lung transplantation. Circulation 1985;71:919-26.

15 Brookes RG, Hofflin JM, Jamieson SW, Stinson EB, Remington JS. Infectious complications in heart-lung transplant recipients. Am J Med 1985;79:412-22.

16 Dummer JS, White LT, Ho M, Griffith BP, Hardesty RL, Bahnson HT. Morbidity of cytomegalovirus infection in recipients of heart or heart-lung transplants who received cyclosporine. J Infect Dis 1985;152:1182-91.

17 Nunan TO, Banatuala JE. Cytomegalovirus infections in renal transplant recipients. $\mathrm{Br} \mathrm{Med} J$ 1984;288:1477-8.
18 Bowden RA, Sayers M, Flourney $\mathrm{N}$, et al. Cytomegalovirus immune globulin and seronegative blood products to prevent primary cytomegalovirus infections after marrow transplantation. $N$ Engl J Med 1986;314:1006-10.

19 Barbara JAJ, Moulsdate H, Brown S, Griffiths PD, Berry MJ. Modified latex agglutination test for anticytomegalovirus suitable for pre-transfusion screening. J Clin Pathol 1987;140:115-6.

20 Collaborative DHPG treatment study group. Treatment of serious cytomegalovirus infection with 9-(1,3dihydroxy-2-propoxymethyl) guanine in patients with AIDS and other immunodeficiency. $N$ Engl $J$ Med 1986;314:801-5.

21 Hughes WT, Kuhns S, Chaudhary S, et al. Succesful chemoprophylaxis for Pneumocystis carinii pneumonitis. N Engl J Med 1977;297:1419-26.

22 Yorakoglu Y, English TAH, Higenbottam TW, Wallwork J. Pneumocystis infections in cardiac transplant recipients [abstract]. Transplantation (in press).

23 McMaster P, Haynes IG, Michael J, et al. Cyclosporine in cadaveric renal transplantation: a prospective randomised trial. Transplant Proc 1983;15:2523-7.

24 McGregor CGA, Baldwin JC, Jamieson SW, et al. Isolated pulmonary rejection after combined heart-lung transplantation. $J$ Thorac Cardiovasc Surg 1985;90:623-30. 